\title{
The Relationship Between the Popularity of Cryptocurrencies and their Prices, Returns and Trading Volumes: A Structural Break and Comparative Analysis
}

\author{
Kripto Paraların Bilinirliği ile Fiyat, Getiri ve İşlem Hacimleri \\ Arasındaki İlişki: Yapısal Kırılmalı ve Karşılaştırmalı Bir Analiz
}

Mustafa ÖZYEŞiL ${ }^{1} \odot$

\begin{abstract}
In this study, the relationship between the popularity of cryptocurrencies and their price, return and trading volumes are examined through time series analysis. The popularity variable is determined according the frequency of cryptocurrencies being searched on the internet. Stationarity of series is examined by Vogelsang and Perron (1998) structural breaks ADF unit root test. According to the test results, all series are found to be stationary at level values. VAR analyses and impulse-response functions are performed to reveal dynamic interaction between the series. According to impulse - response test results, returns of BITCOIN decreased against a decreasing shock in the number searches on the internet and its price and trading volume followed a fluctuating course. In order to see the causality relationship between variables the Granger causality test is conducted. Regression analyses are performed using ordinary least squares (OLS) method through three different equations. According to the result of the regression analysis, an increase in the number of internet searches for cryptocurrencies was found to positively affect prices, returns and trading volumes of all cryptocurrencies. The highest impact on prices and trading volume is observed in BITCOIN, while the highest effect on returns is observed in LITECOIN. According to the findings, popularity can be considered an important determinant for price, returns and trading volumes of cryptocurrencies.
\end{abstract}

Keywords: Cryptocurrencies, popularity, structural break analysis, var analysis

Jel Classification: C31, C33, C51, C 58

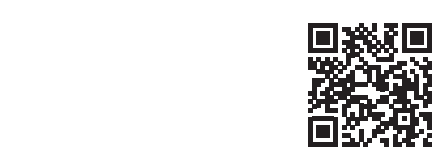

DOI: 10.26650/ISTJECON2019-0017

\begin{abstract}
${ }^{1}$ Assist. Prof. Dr., Istanbul Aydın University, Anadolu BIL Vocational School, Department of Business Administration, Istanbul, Turkey

ORCID: M.Ö. 0000-0002-4442-7087

Corresponding author/Sorumlu yazar: Mustafa ÖZYEŞiL,

Istanbul Aydin University, Anadolu BIL Vocational School, Department of Business Administration (English), Istanbul, Turkey E-mail/E-posta: mozyesil@aydin.edu.tr
\end{abstract}

Submitted/Başvuru: 25.07 .2019
Revision Requested/Revizyon Talebi:
08.11.2019
Last Revision Received/Son Revizyon:
12.11.2019
Accepted/Kabul: 06.12 .2019
Citation/Atıf: Ozyesil, M. (2019). The
relationship between the popularity of
cryptocurrencies and their prices, returns and
trading volumes: A structural break and
comparative analysis. Istanbul iktisat Dergisi -
Istanbul Journal of Economics, $69(2), 133-157$.
https://doi.org/10.26650/ISTJECON2019-0017 


\section{öz}

Bu çalışmada; kripto para tanınırlığı ile kripto paraların fiyatları, getirileri ve işlem hacimleri arasındaki ilişkiler zaman serisi analizi yöntemleriyle incelenmiştir. Bu çalışmada tanınırlık kavramı bağımsız değişken olup kripto paraların internette aranma sayısı olarak ele alınmıştır. Serilerin durağanlığı Vogelsang ve Perron (1998) yapısal kırılmalı ADF birim kök testi ile incelenmiş ve bütün serilerin düzey değerlerinde durağan oldukları tespit edilmiştir. Seriler arasındaki dinamik etkileşimi ortaya çıkarabilmek için VAR analizleri gerçekleştirilmiştir. Bu kapsamda etki-tepki fonksiyonları elde edilmiş ve BITCOIN'in internette aranma sayılarına yönelik azaltıcı bir şok karşısında getirisinin azaldığı, fiyat ve işlem hacminin dalgalı bir seyir izlediği tespit edilmiştir. Modelde yer alan değişkenler arası nedensellik ilişkisini ortaya koyabilmek amacıyla Granger nedensellik testi yapılmıştır. Regresyon analizleri üç farklı denklem yardımıyla, EKK yöntemiyle yapılmıştır Analiz sonuçlarına göre, kripto paralara yönelik internette aranma sayısındaki artışın, bütün kripto paraların fiyatlarını, getirilerini ve işlem hacimlerini olumlu yönde etkilediği tespit edilmiştir. Fiyatlar ve işlem hacmi noktalarındaki en büyük etkinin BITCOIN'de, getiriler noktasındaki en yüksek etkinin ise LITECOIN'de yaşandığı belirlenmiştir. Çalışmada elde edilen bulgulara dayanılarak; kripto paraların tanınırığının fiyat, işlem hacmi ve getirileri üzerinde önemli bir belirleyici faktör olduğu sonucuna varılmıştır.

Anahtar kelimeler: Kripto paralar, tanınırlık, yapısal kırılmalı analiz, var analizi

Jel Kod: C31, C33, C51, C 58

\section{Introduction}

The topic of cryptocurrencies has become increasingly popular in today's financial world. Unlike the concept of traditional money which is subject to physical circulation, the most important feature of cryptocurrency is that it is digital money. In other words, money that has payment function for the purpose of purchasing goods and services on the market is subject to exchange in a virtual or digital environment rather than through physical circulation. It is clear that the first and perhaps the most popular example of cryptocurrency is BITCOIN which was created in 2008 by unknown people under the nickname of Satoshi Nakamoto. The rapid increase and huge fluctuation observed in prices have grabbed the attention of the financial world on BITCOIN and indirectly on cryptocurrency concept. Thereupon, many cryptocurrencies have been issued like BITCOIN. The governments of many countries have even decided to create their own cryptocurrency. Currently, there are about 2.500 cryptocurrencies involved in trade. There are different approaches and legal regulations in countries related to BITCOIN and other cryptocurrencies. While some countries have completely banned cryptocurrencies, other countries have decided to issue their own cryptocurrencies. The factor that makes cryptocurrencies so popular is 
that they do not have a central structure, in other words, they are not controlled by the central banks of any country (Böhme and Christin, 2015).

Cryptocurrencies, which can be regarded as a financial revolution that will radically change the concept and definition of the concept of conventional money in the world, have also intensively increased in popularity in academic studies.

In the majority of studies, the question arises of whether cryptocurrencies will replace national currencies as a means of payment tool and whether they will become an alternative investment tool for the financial instruments in financial markets.

In this study, as explained in the following chapters, an original analysis of cryptocurrencies is made to contribute to the literature. Thus, we attempt to determine the relationship between the popularity of cryptocurrencies and their price, returns and trading volumes through structural break analysis. In addition, VAR analysis is performed to find out the interactions between cryptocurrencies and their popularity.

\section{Data and Methodology}

The main objective of this study is to investigate the relationship between the number searches (frequency of being searched) on the Internet and the price, returns and trading volumes for cryptocurrencies. In order to analyze the abovementioned relationship, the month-end closing prices (PR), monthly trading volumes (VOL), monthly returns (RT) and monthly frequency of internet searches (ST) of the 6 cryptocurrencies with the longest data period was used. Returns data were used in the analysis as monthly percentage change using day-end closing data obtained from www.investing.com.

For the purpose of obtaining the frequency of searches on the internet for the crypto currencies, index data indicating the degree of importance (popularity) generated by Google's google.trends.com (Google, 2019) based on the number 
of monthly searches of cryptocurrencies were used. Index gets values in the range of [0-100] and the increase in this index value indicates that the relevant cryptocurrency is searched more on the internet than other cryptocurrencies.

Cryptocurrencies that have highest trading volumes are included in the sample. The widest possible data range was included in the study and for this purpose; the transaction dates of each cryptocurrencies that are included in the sample are matched. As a result, 6 cryptocurrencies with the highest transaction volume and sufficient observations are included in the final sample. Cryptocurrencies analyzed and the related data periods available for this study are shown in Table 1.

Table 1: Cryptocurrencies Used in Analysis

\begin{tabular}{|l|c|c|}
\hline No & CryptoCurrency & Analysis Period \\
\hline 1 & BITCOIN & 2010:M07-2019:M05 \\
\hline 2 & RIPPLE-XRP & 2015:M01-2019:M05 \\
\hline 3 & ETHEREUM & 2016:M03-2019:M05 \\
\hline 4 & ETHEREUM CLASSIC & 2016:M06-2019:M05 \\
\hline 5 & LITECOIN & 2016:M08-2019:M05 \\
\hline 6 & ZCASH & 2016:M10-2019:M05 \\
\hline
\end{tabular}

Note: The data in the table are organized in the order in which the relevant currency is traded on the market.

As can be observed in Table 1, since the initial trading date of cryptocurrency is different, a separate time series analysis was made for each cryptocurrency and the findings were compared. Although there were 13 cryptocurrencies in the first form of the sample, cryptocurrencies with less than 30 observations were excluded from the analysis in order to perform a reliable time series analysis.

\section{Findings}

Two main analyzes were carried out in this study. The first one was to determine the relationship between the popularity of cryptocurrencies and their price, returns and trading volume. The second was to analyze interactions among cryptocurrencies included in the sample. 


\subsection{Comparative Time Series Analysis to Investigate the Relationship between Frequency of Internet Searches of Cryptocurrencies and Their Price, Returns and Trading Volume}

In this part of the study, we first examine the stationarity of the series and, according to the results obtained from tests, analysis methods to be performed are determined.

\subsubsection{Unit Root Test}

In this study, the stationarity of the series was investigated by structural break ADF unit root test developed by Vogelsang and Perron (1998). This test can internally determine the structural break in the series and can perform the unit root test by considering this structural break.

Test hypotheses:

$H_{0:}$ The series is not stationary.

$H_{1}$ : The series is stationary.

According to the results shown on Table 2, all series are stationary at level values. In this case, there will no spurious regression problem in the analysis based on the level values. Therefore, the cointegration test was not required. Instead, Regression analysis, VAR analysis and Granger Causality tests can be performed using the level values of the series. When structural breakdown dates determined by the test method are examined, it can be inferred that there is a structural break in December 2017, Factors that lie behind this structural breakdown in the afore-mentioned date are the legal recognition of Bitcoin and all of other digital currencies by Japan in April 2017 (Habertürk, 2017) and Ukraine's legalization of Bitcoin in October 2017 (Siberbülten, 2017).

The results of structural break ADF unit root test are presented in Table 2, 
Table 2: Vogelsang and Perron (1998) Structural Break ADF Unit Root Test Results

\begin{tabular}{|c|c|c|c|c|c|}
\hline $\begin{array}{l}\text { Crypto } \\
\text { Currencies }\end{array}$ & Variable & $\begin{array}{c}\text { Optimum Lag } \\
\text { Length }\end{array}$ & $t$-Statistics & $\begin{array}{c}\text { Probability } \\
\text { Value }\end{array}$ & $\begin{array}{c}\text { Structural Break } \\
\text { Date }\end{array}$ \\
\hline \multirow{4}{*}{ BITCOIN } & PR & 1 & $-5,088 * \star \star$ & 0,00 & 2017:M07 \\
\hline & RT & 0 & $-10,23^{* \star *}$ & 0,00 & 2011:M05 \\
\hline & VOL & 1 & $-9,58^{* * *}$ & 0,00 & 2018:M04 \\
\hline & ST & 1 & $-8,19 * \star \star$ & 0,00 & 2017:M12 \\
\hline \multirow{4}{*}{ RIPPLE-XRP } & PR & 0 & $-4,80^{* *}$ & 0,01 & 2017:M11 \\
\hline & RT & 0 & $-7,58^{\star \star \star}$ & 0,00 & 2017:M05 \\
\hline & VOL & 0 & $-5,57^{\star \star}$ & 0,01 & 2015:M12 \\
\hline & ST & 0 & $-4,81^{* *}$ & 0,01 & 2018:M01 \\
\hline \multirow{4}{*}{ ETHEREUM } & PR & 0 & $-9,10^{* * *}$ & 0,00 & 2017:M12 \\
\hline & RT & 0 & $-5,13^{* * *}$ & 0,00 & 2017:M06 \\
\hline & VOL & 2 & $-8,16^{\star * *}$ & 0,00 & 2018:M09 \\
\hline & ST & 1 & $-4,77^{\star \star}$ & 0,01 & 2017:M12 \\
\hline \multirow{4}{*}{$\begin{array}{l}\text { ETHEREUM } \\
\text { CLASSIC }\end{array}$} & PR & 1 & $-8,40 * \star \star$ & 0,00 & 2017:M11 \\
\hline & RT & 0 & $-4,98 * * *$ & 0,00 & 2017:M05 \\
\hline & VOL & 4 & $-4,61^{* *}$ & 0,04 & 2018:M01 \\
\hline & ST & 1 & $-5,61^{\star \star \star}$ & 0,00 & 2018:M01 \\
\hline \multirow{4}{*}{ LITECOIN } & PR & 5 & $-5,76^{\star * *}$ & 0,00 & 2017:M12 \\
\hline & $\mathrm{RT}$ & 0 & $-6,59 * * \star$ & 0,00 & 2017:M12 \\
\hline & VOL & 1 & $-4,86^{\star \star}$ & 0,04 & 2019:M01 \\
\hline & ST & 3 & $-11,83^{* \star *}$ & 0,00 & 2017:M12 \\
\hline \multirow{4}{*}{ ZCASH } & PR & 0 & $-10,18^{* * *}$ & 0,00 & 2018:M01 \\
\hline & RT & 0 & $-5,01^{\star * *}$ & 0,00 & 2017:M06 \\
\hline & VOL & 1 & $-4,89 * \star$ & 0,01 & 2019:M02 \\
\hline & ST & 0 & $-6,07 * \star *$ & 0,00 & 2017:M10 \\
\hline
\end{tabular}

Note: $* \star *$ and ${ }^{* *}$ indicate that the relevant variable is stationary at $1 \%$ and $5 \%$ significance level, respectively. Optimum lag lengths were determined according to the Schwarz Information Criteria (SIC).

Therefore, December 2017 is included in the regression analysis as the dummy variable (K2017). While creating this variable, 1 is assigned to December 2017 and 0 is assigned to other periods.

\subsubsection{Regression Analysis}

As the series is stationary in their level values, the relationships between the series can be investigated by regression analysis. To conduct regression analysis, the LS (Least Squares) method will be used. The reasons for preferring this method are that the number of observations on the cryptocurrencies other than 
Bitcoin is low, the LS method does not require lag and premise values, and thus the degree of freedom and reliability of the estimates will be high.

Econometric models used in regression analysis:

$$
\begin{aligned}
& P R_{t}=\beta_{0}+\beta_{1} S T_{t}+e_{t} \\
& R T_{t}=a_{0}+a_{1} S T_{t}+u_{t} \\
& V O L_{t}=\theta_{0}+\theta_{1} S T_{t}+v_{t}
\end{aligned}
$$

Regression analyses were performed based on these equations and the results

\begin{tabular}{|c|c|c|c|c|c|c|}
\hline $\begin{array}{l}\text { Crypto } \\
\text { Currencies }\end{array}$ & $\begin{array}{c}\text { Dependent } \\
\text { Variable }\end{array}$ & ST & K2017 & $R^{2}$ & $\bar{R}^{2}$ & F-Statistics \\
\hline \multirow{3}{*}{ BITCOIN } & PR & $271,62^{\star * *}(0,00)$ & $-12242,55^{* * *}(0,00)$ & 0,80 & 0,79 & $210,26^{* * *}(0,00)$ \\
\hline & RT & $2,06 *(0,09)$ & \begin{tabular}{|l|}
$-113,30(0,36)$ \\
\end{tabular} & 0,24 & 0,21 & $9,65^{\star * *}(0,00)$ \\
\hline & VOL & $407,92 *(0,06)$ & $-36193,99 *(0,09)$ & 0,41 & 0,40 & $155,17^{\star * \star}(0,00)$ \\
\hline \multirow{3}{*}{$\begin{array}{l}\text { RIP- } \\
\text { PLE-XRP }\end{array}$} & ST & $0,01^{* * *}(0,00)$ & $-0,98 * * *(0,00)$ & 0,79 & 0,78 & $95,70 * * *(0,00)$ \\
\hline & PR & $0,99 * * \star(0,00)$ & $142,38^{* \star *}(0,00)$ & 0,12 & 0,09 & $3,52^{\star *}(0,03)$ \\
\hline & RT & $59,66^{* *}(0,03)$ & $2921,23 * \star(0,02)$ & 0,55 & 0,17 & $14,73^{* * *}(0,00)$ \\
\hline \multirow{3}{*}{ ETHEREUM } & VOL & $11,50^{* * *}(0,00)$ & $-588,08^{* *}(0,01)$ & 0,56 & 0,54 & $23,57^{* * *}(0,00)$ \\
\hline & ST & $1,12^{\star \star \star}(0,00)$ & $-31,12(0,17)$ & 0,28 & 0,24 & $7,09 * \star \star *(0,00)$ \\
\hline & PR & $6,25^{\star \star}(0,03)$ & $-589,26^{\star \star}(0,04)$ & 0,13 & 0,08 & $2,80 *(0,07)$ \\
\hline \multirow{3}{*}{$\begin{array}{l}\text { ETHEREUM } \\
\text { CLASSIC }\end{array}$} & RT & $0,29 * * *(0,00)$ & $-1,58(0,77)$ & 0,71 & 0,70 & $40,75^{\star \star *}(0,00)$ \\
\hline & VOL & $1,44 *(0,07)$ & $-133,54^{* *}(0,01)$ & 0,15 & 0,09 & $2,76 *(0,07)$ \\
\hline & ST & $6,30 * * *(0,00)$ & $-571,84^{\star \star \star}(0,00)$ & 0,14 & 0,08 & $2,65 *(0,08)$ \\
\hline \multirow{3}{*}{ LITECOIN } & PR & $5,21 * * *(0,00)$ & $-311,23 * * *(0,00)$ & 0,70 & 0,68 & $36,23^{* \star *}(0,00)$ \\
\hline & RT & $14,78^{* * *}(0,00)$ & $-1243,56^{* * *}(0,00)$ & 0,30 & 0,25 & $6,40^{* \star *}(0,00)$ \\
\hline & VOL & $12,81^{\star \star \star}(0,00)$ & $-1108,10^{* * *}(0,00)$ & 0,92 & 0,91 & $161,57^{\star \star \star}(0,00)$ \\
\hline \multirow{3}{*}{ ZCASH } & ST & $3,81^{* * *}(0,00)$ & $-142,18(0,11)$ & 0,59 & 0,56 & $20,75^{\star \star \star}(0,00)$ \\
\hline & PR & $1,09 * *(0,01)$ & $-27,99(0,58)$ & 0,25 & 0,19 & $4,74 * \star(0,01)$ \\
\hline & RT & $32,94(0,55)$ & $4084,28(0,25)$ & 0,38 & 0,34 & $9,00 * * *(0,00)$ \\
\hline
\end{tabular}
are presented on Table 3,

Table 3: Regression Analysis Results

Note: $* * *$ and $* *$ indicate that the relevant variable is stationary at $1 \%$ and $5 \%$ significance level, respectively. Numbers in parentheses represent the probability value.

According to the results on Table 3, the increase in the number of searches on the internet positively affected the prices, returns and trading volumes of all crypto currencies. The greatest impact was observed for price and volume in BITCOIN and in returns in LITECOIN. 


\subsection{VAR Analysis}

VAR (Vector Autoregressive) analysis is an effective analysis system to reveal the interactions between static variables without the need for internal and external variable distinction. In order to perform VAR analysis between $X$ and $Y$ variables, the following equation is used (Dikmen, 2012):

$$
\begin{aligned}
& Y_{t}=\alpha_{0}+\sum_{i=1}^{m} \alpha_{i} Y_{t-i}+\sum_{i=1}^{m} \beta_{i} X_{t-i}+u_{t} \\
& X_{t}=\gamma_{0}+\sum_{i=1}^{m} \gamma_{i} X_{t-i}+\sum_{i=1}^{m} \varphi_{i} Y_{t-i}+\vartheta_{t}
\end{aligned}
$$

Here $m$ refers to the optimum lag length. In this study, VAR estimates were made for each cryptocurrency separately. In the VAR analysis method, the first step is determining the appropriate lag length and then autocorrelation and heteroscedasticity tests will be performed for VAR models based on this lag length. Optimum lag length, autocorrelation test and heteroscedasticity test were performed and results are presented on Table 4.

\begin{tabular}{|c|c|c|c|c|}
\hline & $\begin{array}{l}\text { Lag } \\
\text { Length }\end{array}$ & Criteria & $\begin{array}{c}\text { Autocorrelation } \\
\text { Test }\end{array}$ & $\begin{array}{c}\text { Heteroscedastici- } \\
\text { ty Test }\end{array}$ \\
\hline BITCOIN & 10 & LR, FPE, SC & $16,36 * * *(0,42)$ & $838,73 * * \star(0,16)$ \\
\hline RIPPLE-XRP & 2 & $\mathrm{SC}, \mathrm{HQ}$ & $16,51^{* \star *}(0,41)$ & $444,91^{* * *}(0,19)$ \\
\hline ETHEREUM & 2 & FPE, AIC & $10,00 * * *(0,86)$ & $179,95^{\star \star \star}(0,13)$ \\
\hline ETHEREUM CLASSIC & 2 & LR, FPE, AIC, HQ & $10,04^{* * *}(0,86)$ & $168,21^{* * *}(0,31)$ \\
\hline LITECOIN & 2 & FPE & $21,28 * * *(0,16)$ & $172,91 * * *(0,22)$ \\
\hline ZCASH & 1 & LR, FPE, AIC, SC, HQ & $18,92^{\star * *}(0,27)$ & $111,83^{\star * *}(0,19)$ \\
\hline
\end{tabular}

Table 4: Optimum Lag Length Determination Results

Note: AIC: Akaike Information Criterion), LR: Lagrange Ratio, sequential modified LR test statistic, FPE: Final Prediction Error, SC: Schwarz Information Criterion, HQ: Hannan-Quinn Information Criterion. *** indicates that there is no related problem in the model at $\% 1$ significance level. The maximum lag length is limited to 3 because of the small number of observations exist in the series except BITCOIN. Thus, as a result of this estimation, the problems related to the decrease of the degrees of freedom and the decrease in the reliability of the VAR models are prevented.

In order to test the stability of the created VAR models, the charts of inverse AR roots are generated and presented in Figure 1, In these charts, the fact that the inverse characteristic roots remain within the unit circle shows that the 
corresponding VAR model is stable (Tarl, 2012). In the graphs obtained from Figure 1 , it is decided that the estimated VAR models are stable because the inverse roots remained within the unit circle.

Figure 1: Charts of Inverse Characteristic Roots of VAR Models

a. BITCOIN

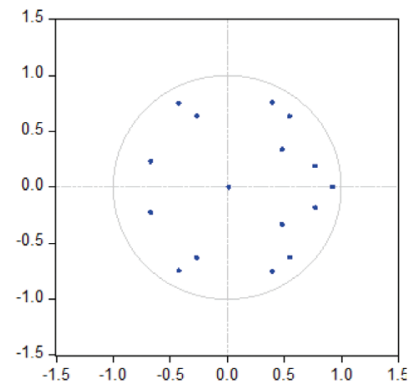

c. ETHEREUM

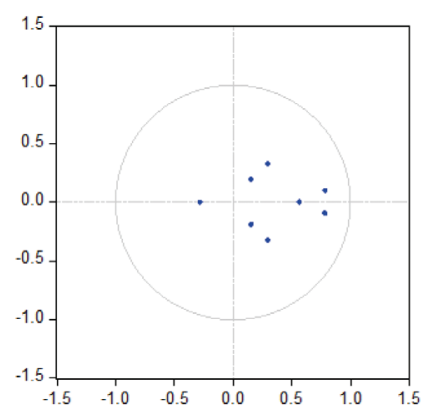

e. LITECOIN

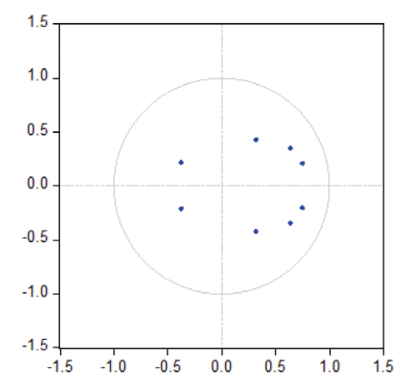

b. RIPPLE-XRP

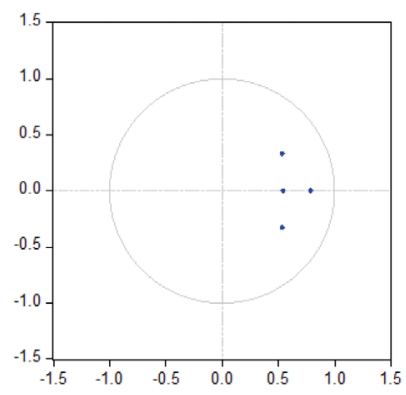

d. ETHEREUM CLASSIC

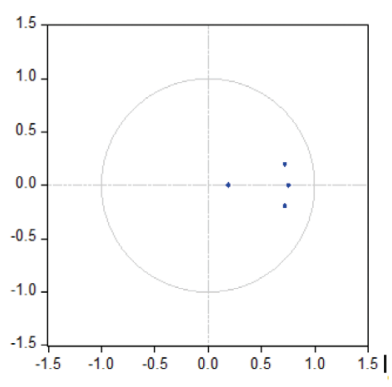

f. ZCASH

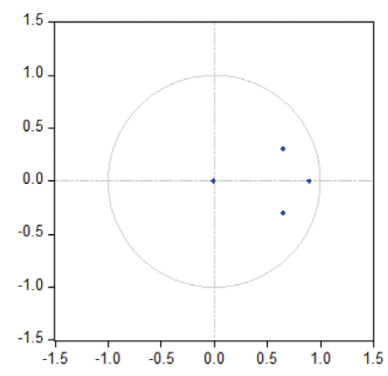

The direct interpretation of the parameters in VAR models may not be meaningful (Tarı, 2012). For this reason, in this study, firstly the impulse-response functions and then the variance decomposition will be examined respectively. 


\subsubsection{Impulse-Response Functions}

This analysis examines the response of the variables to their own or other variables' shocks (Impulse-Response). A standard-error shock (effect) occurring in one of the variables is examined by the responses of other variables.

The responses of the other variables against a decreasing shock for BITCOIN's Internet search numbers are shown in Figure 2.

Figure 2: The Response of Other Variables against a Reducing Shock to the Frequency of BITCOIN Being Searched on the Internet

Response to Cholesky One S.D. (d.f. adjusted) Innovations \pm 2 S.E.

Response of FIY to SAY

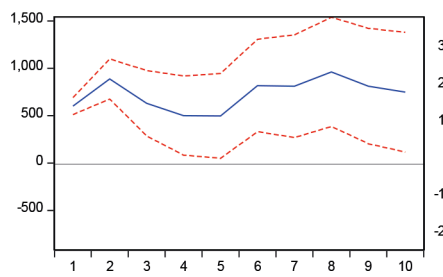

Response of GET to SAY

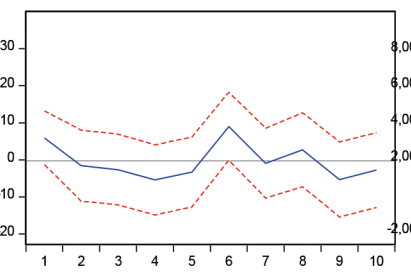

Response of HAC1 to SAY

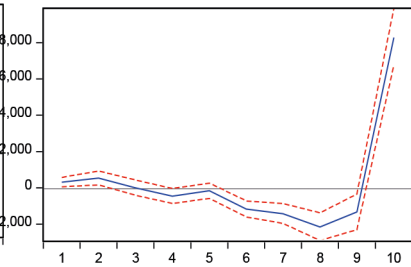

According to Figure 2, it can be observed that the return of BITCOIN decreases against the decreasing shock of frequency internet searches but the price and volume fluctuates.

The responses of the other variables against an increasing shock for RIPPLEXRP's frequency of being searched on the internet are shown in Figure 3.

Figure 3: The Response of Other Variables against an Increasing Shock to the Frequency of Internet Searches of RIPPLE-XRP

Response to Cholesky One S.D. (d.f. adjusted) Innovations \pm 2 S.E.

Response of FIY to SAY

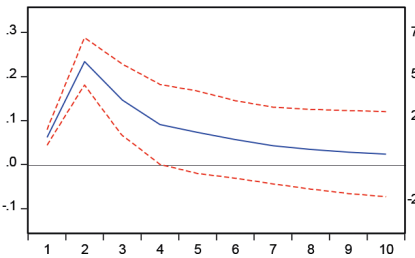

Response of GET to SAY

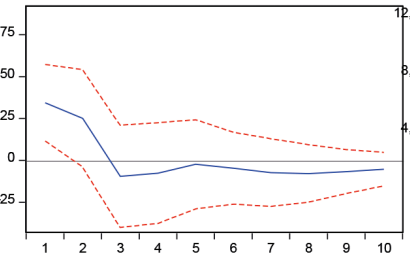

Response of HAC1 to SAY

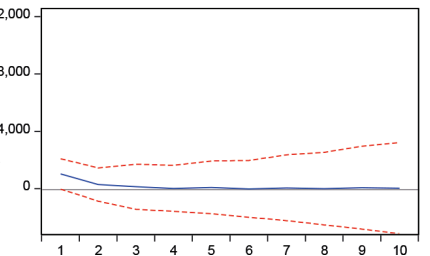


According to Figure 3, the price of RIPPLE-XRP increases in response to the increasing shock of frequency of internet searches, return decreases and the trading volume does not provide meaningful reaction.

The responses of the other variables against an increasing shock for ETERHEUM's frequency of internet searches are shown in Figure 4.

Figure 4: The Response of Other Variables against to an Increasing Shock to the Frequency of Being Searched on Internet of ETERHEUM

Response to Cholesky One S.D. (d.f. adjusted) Innovations \pm 2 S.E.

Response of FIY to SAY

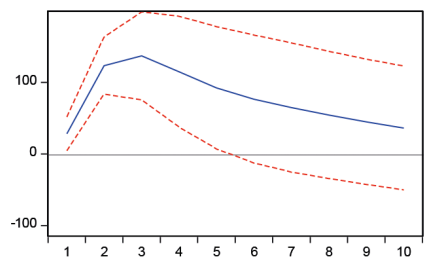

Response of GET to SAY

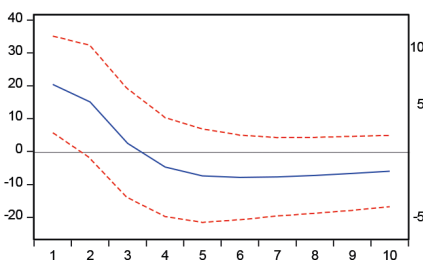

Response of HAC11 to SAY

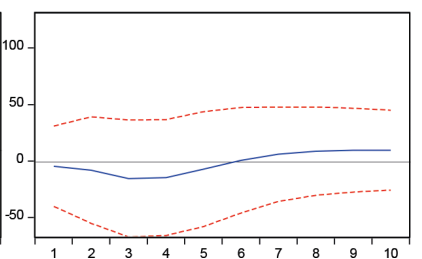

According to Figure 4, the price of ETERHEUM increases in response to the increasing shock of frequency of internet searches, return decreases and the trading volume fluctuates.

The responses of the other variables against a decreasing shock for ETERHEUM CLASSIC's frequency of internet searches are shown in Figure 5.

Figure 5: The Response of Other Variables against a Reducing Shock to the Frequency of Internet searches of ETERHEUM CLASSIC

Response to Cholesky One S.D. (d.f. adjusted) Innovations \pm 2 S.E.

Response of FIY to SAY

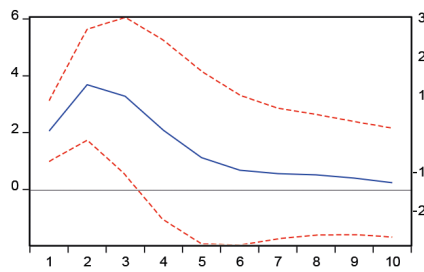

Response of GET to SAY

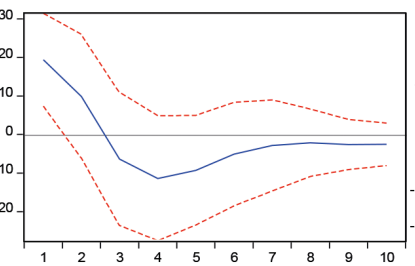

Response of HAC1 to SAY

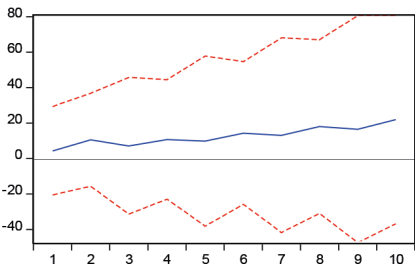


According to Figure 5, the price of ETERHEUM CLASSIC increases in response to the decreasing shock of frequency of internet searches, return decreases and the trading volume fluctuates.

The responses of the other variables against a decreasing shock for LITECOIN's frequency of internet searches are shown in Figure 6.

Figure 6: The Response of Other Variables against a Decreasing Shock to the Frequency of Internet searches of LITECOIN

Response to Cholesky One S.D. (d.f. adjusted) Innovations \pm 2 S.E.
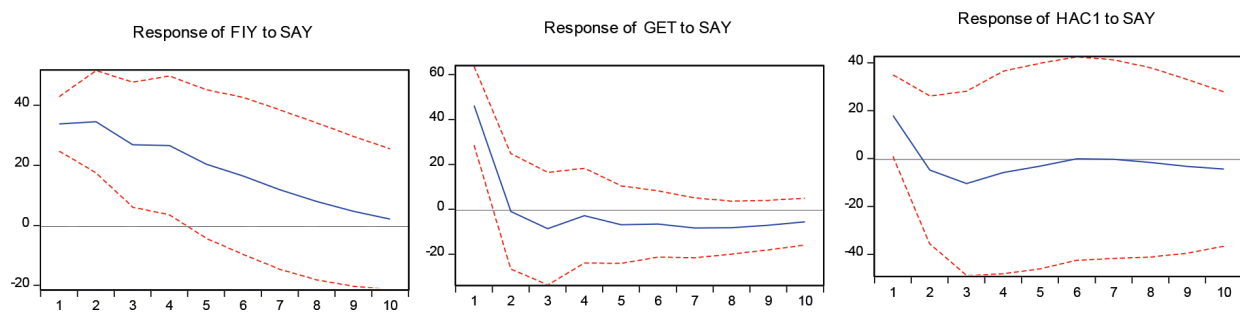

According to Figure 6, the price, return and volume of LITECOIN decrease in response to the decreasing shock of frequency of on internet searches.

The responses of the other variables against a decreasing shock for ZCASH frequency of internet searches are shown in Figure 7.

Figure 7: The Response of Other Variables against a Decreasing Shock to the Frequency of Internet Searches of ZCASH

Response to Cholesky One S.D. (d.f. adjusted) Innovations \pm 2 S.E.

Response of FIY to SAY

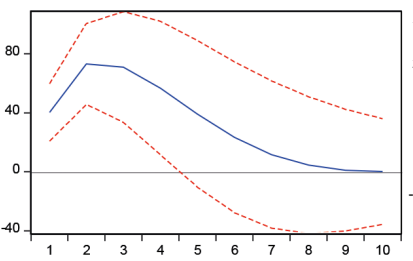

Response of GET to SAY

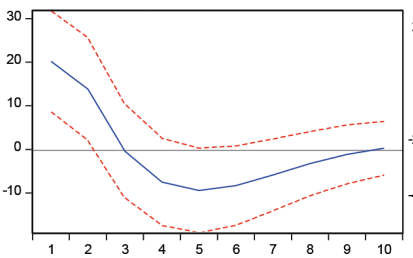

Response of HAC1 to SAY

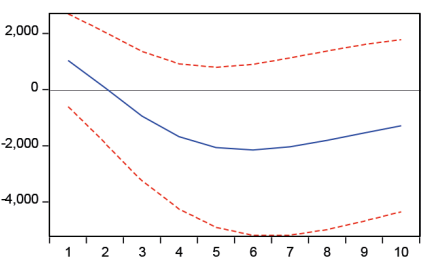

According to Figure 7, the price of ZCASH first increased and then decreased in response to the decreasing shock of frequency of internet searches. The volume and return responded in a decreasing way. 


\subsubsection{Variance Decomposition Analysis}

Variance decomposition method is used to determine how much of the change that occurred in each variable is due to changes experienced in other variables (Tarı, 2012, p. 469). In this analysis, the values in the first period in which the distribution reaches equilibrium are interpreted. In this study, different variance decompositions are made for each cryptocurrency and the findings are presented on the tables below. The related results of variance decomposition performed for BITCOIN are given on Table 5 .

Table 5: Variance Decomposition Results for BITCOIN

\begin{tabular}{|c|c|c|c|c|c|}
\hline \multicolumn{6}{|c|}{ Variance Decomposition of PR: } \\
\hline Period & S.E. & ST & PR & RT & VOL \\
\hline 1 & 614,0358 & 95,59181 & 4,408192 & 0,000000 & 0,000000 \\
\hline 2 & 1118,065 & 91,69569 & 8,001020 & 0,224846 & 0,078443 \\
\hline 3 & 1559,997 & 63,39573 & 36,35046 & 0,200317 & 0,053493 \\
\hline 4 & 1821,214 & 54,05442 & 45,45102 & 0,150075 & 0,344490 \\
\hline 5 & 1994,089 & 51,28961 & 47,96497 & 0,383843 & 0,361573 \\
\hline 6 & 2302,279 & 51,06367 & 48,04890 & 0,452864 & 0,434570 \\
\hline 7 & 2521,459 & 52,89122 & 46,01573 & 0,645068 & 0,447974 \\
\hline 8 & 2719,100 & 57,98327 & 40,70957 & 0,887982 & 0,419171 \\
\hline 9 & 2845,529 & 61,06898 & 37,32591 & 1,042402 & 0,562717 \\
\hline 10 & 2952,793 & 63,11907 & 35,07430 & 1,147293 & 0,659341 \\
\hline 11 & 3092,302 & 64,85315 & 33,35275 & 1,149766 & 0,644333 \\
\hline 12 & 3240,460 & 66,13936 & 31,84668 & 1,098588 & 0,915367 \\
\hline 13 & 3318,277 & 65,93901 & 32,13011 & 1,057809 & 0,873074 \\
\hline 14 & 3337,209 & 65,45197 & 32,22583 & 1,105640 & 1,216560 \\
\hline 15 & 3349,819 & 64,97433 & 32,29413 & 1,133672 & 1,597869 \\
\hline 16 & 3379,321 & 64,47195 & 32,05268 & 1,172887 & 2,302486 \\
\hline \multicolumn{6}{|c|}{ Variance Decomposition of RT: } \\
\hline Period & S.E. & ST & PR & RT & VOL \\
\hline 1 & 35,64527 & 2,759969 & 1,623889 & 95,61614 & 0,000000 \\
\hline 2 & 38,16487 & 2,577910 & 1,417113 & 94,80429 & 1,200682 \\
\hline 3 & 38,65745 & 2,981714 & 3,337159 & 92,43473 & 1,246395 \\
\hline 4 & 39,37933 & 4,763356 & 3,554377 & 90,00955 & 1,672713 \\
\hline 5 & 39,81432 & 5,350516 & 4,564252 & 88,37250 & 1,712732 \\
\hline 6 & 42,07344 & 9,389552 & 8,348404 & 80,40181 & 1,860231 \\
\hline 7 & 42,40329 & 9,292316 & 8,901651 & 79,96345 & 1,842582 \\
\hline 8 & 44,43265 & 8,830667 & 14,97202 & 74,51378 & 1,683535 \\
\hline 9 & 45,56078 & 9,766557 & 15,35213 & 72,90689 & 1,974430 \\
\hline 10 & 45,69827 & 10,07394 & 15,38259 & 72,51932 & 2,024156 \\
\hline \multicolumn{6}{|c|}{ Variance Decomposition of VOL: } \\
\hline Period & S.E. & ST & PR & RT & VOL \\
\hline 1 & 1291,121 & 5,984378 & 0,730275 & 3,374944 & 89,91040 \\
\hline 2 & 1665,810 & 14,30324 & 1,649894 & 3,624228 & 80,42263 \\
\hline 3 & 1696,037 & 13,79959 & 1,610175 & 3,499166 & 81,09107 \\
\hline 4 & 1778,368 & 19,18128 & 2,704346 & 3,269617 & 74,84476 \\
\hline 5 & 1814,412 & 19,20980 & 4,147018 & 3,176963 & 73,46621 \\
\hline 6 & 2173,878 & 41,97924 & 3,118190 & 2,224034 & 52,67853 \\
\hline 7 & 2668,253 & 56,17220 & 4,132979 & 1,516729 & 52,17810 \\
\hline
\end{tabular}


According to the results presented on Table 5, 65,9\% of the change in BITCOIN's prices, $9,7 \%$ of the changes in BITCOIN's returns and $41,9 \%$ of the changes in BITCOIN's trading volume are determined by frequency of internet searches. In other words, when BITCOIN's number of internet searches increases, its price, return and trading volume are expected to also increase. The results of the variance decomposition made for RIPPLE-XRP are presented on Table 6.

Table 6: Variance Decomposition Results for RIPPLE-XRP

\begin{tabular}{|c|c|c|c|c|c|}
\hline \multicolumn{7}{|c|}{ Variance Decomposition of PR: } \\
\hline Period & S.E. & ST & PR & RT & VOL \\
\hline 1 & 0,076438 & 65,28590 & 34,71410 & 0,000000 & 0,000000 \\
\hline 2 & 0,250511 & 93,55466 & 4,312525 & 2,130079 & 0,002740 \\
\hline 3 & 0,291458 & 94,45831 & 3,674288 & 1,705982 & 0,161416 \\
\hline 4 & 0,307782 & 93,42907 & 3,334015 & 1,568089 & 1,668824 \\
\hline 5 & 0,319128 & 92,11406 & 3,121397 & 1,576334 & 3,188213 \\
\hline 6 & 0,329732 & 89,24654 & 2,929973 & 1,583737 & 6,239751 \\
\hline 7 & 0,338616 & 86,22995 & 2,782692 & 1,544877 & 9,442479 \\
\hline \multicolumn{7}{|c|}{ Variance Decomposition of RT: } \\
\hline Period & S.E. & ST & PR & RT & VOL \\
\hline 1 & 84,30718 & 16,57949 & 1,183085 & 82,23742 & 0,000000 \\
\hline 2 & 100,7917 & 17,75208 & 1,034642 & 81,19884 & 0,014431 \\
\hline 3 & 101,4664 & 18,41337 & 1,054373 & 80,14047 & 0,391795 \\
\hline 4 & 102,8837 & 18,46207 & 1,118646 & 79,93273 & 0,486550 \\
\hline 5 & 103,6195 & 18,25542 & 1,215899 & 79,92066 & 0,608015 \\
\hline \multicolumn{7}{|c|}{ Variance Decomposition of VOL: } \\
\hline Period & S.E. & ST & PR & RT & VOL \\
\hline 1 & 3813,742 & 7,364242 & 0,000632 & 0,832285 & 91,80284 \\
\hline 2 & 3905,212 & 7,586365 & 0,512855 & 0,811016 & 91,08977 \\
\hline 3 & 5465,927 & 3,938403 & 0,293934 & 0,431649 & 95,33601 \\
\hline 4 & 5677,497 & 3,652209 & 0,349464 & 0,455365 & 95,54296 \\
\hline 5 & 6957,752 & 2,452302 & 0,248167 & 0,306176 & 96,99336 \\
\hline 6 & 7328,219 & 2,210901 & 0,247442 & 0,294975 & 97,24668 \\
\hline 7 & 8535,017 & 1,635695 & 0,190404 & 0,220832 & 97,95307 \\
\hline 9 & 9087,515 & 1,442915 & 0,178005 & 0,210277 & 98,16880 \\
\hline \multicolumn{7}{|c|}{10316,77} & 1,125956 & 0,140887 & 0,168785 & 98,56437 \\
\hline
\end{tabular}

According to the results on Table $6,89,2 \%$ of the change in RIPPLE-XRP's prices, $18,4 \%$ of the changes in RIPPLE-XRP's returns and $1,4 \%$ of the changes observed in RIPPLE-XRP's trading volume are determined by the frequency of 
internet searches. Based on these findings, it can be stated that when RIPPLE-XRP's number of internet searches increase, particularly its price and its return are expected to increase.

The results of the variance decomposition made for ETHERUM are presented on Table 7.

Table 7: Variance Decomposition Results for ETHERUM

\begin{tabular}{|c|c|c|c|c|c|}
\hline \multicolumn{6}{|c|}{ Variance Decomposition of PR: } \\
\hline Period & S.E. & ST & PR & RT & VOL \\
\hline 1 & 73,60023 & 14,68362 & 85,31638 & 0,000000 & 0,000000 \\
\hline 2 & 145,7485 & 75,30711 & 23,73985 & 0,816990 & 0,136043 \\
\hline 3 & 201,3208 & 85,82227 & 12,55984 & 1,292600 & 0,325294 \\
\hline 4 & 232,5593 & 88,70820 & 9,412331 & 1,076718 & 0,802753 \\
\hline 5 & 251,6493 & 89,24925 & 8,125977 & 0,921167 & 1,703607 \\
\hline 6 & 264,8815 & 88,92539 & 7,520092 & 0,845244 & 2,709278 \\
\hline 7 & 274,4550 & 88,40446 & 7,202925 & 0,826670 & 3,565949 \\
\hline 8 & 281,2874 & 87,90988 & 7,032910 & 0,846167 & 4,211043 \\
\hline 9 & 286,0248 & 87,48707 & 6,947728 & 0,886826 & 4,678375 \\
\hline 10 & 289,2200 & 87,13939 & 6,912162 & 0,935331 & 5,013116 \\
\hline \multicolumn{6}{|c|}{ Variance Decomposition of RT: } \\
\hline Period & S.E. & ST & PR & RT & VOL \\
\hline 1 & 46,42854 & 19,35259 & 28,45463 & 52,19278 & 0,000000 \\
\hline 2 & 49,96662 & 25,81323 & 24,90563 & 46,29308 & 2,988057 \\
\hline 3 & 51,40484 & 24,62892 & 23,99403 & 47,52034 & 3,856709 \\
\hline 4 & 52,41683 & 24,50046 & 23,49399 & 47,47328 & 4,532264 \\
\hline 5 & 53,40150 & 25,51135 & 23,00732 & 46,80211 & 4,679224 \\
\hline 6 & 54,16043 & 26,91637 & 22,50684 & 45,97452 & 4,602275 \\
\hline 7 & 54,77015 & 28,29166 & 22,04442 & 45,16228 & 4,501635 \\
\hline \multicolumn{6}{|c|}{ Variance Decomposition of VOL: } \\
\hline Period & S.E. & ST & PR & RT & VOL \\
\hline 1 & 106,5613 & 0,191397 & 0,051696 & 1,135157 & 98,62175 \\
\hline 2 & 136,6975 & 0,472412 & 0,306119 & 0,788080 & 98,43339 \\
\hline 3 & 147,1401 & 1,511455 & 1,134623 & 1,355677 & 95,99824 \\
\hline 4 & 151,2772 & 2,372346 & 1,470451 & 2,149655 & 94,00755 \\
\hline 5 & 153,0075 & 2,545459 & 1,682602 & 2,916998 & 92,85494 \\
\hline 6 & 153,8405 & 2,519597 & 1,830790 & 3,455255 & 92,19436 \\
\hline 7 & 154,4006 & 2,651322 & 1,925902 & 3,772656 & 91,65012 \\
\hline 8 & 154,8529 & 2,949554 & 1,970908 & 3,930391 & 91,14915 \\
\hline
\end{tabular}


According to the results on Table 7,87,4\% of the change occurred in ETHEREUM's prices, $26,9 \%$ of the changes in ETHEREUM's returns and 2,6\% of the changes in ETHEREUM's trading volume are determined by the frequency of internet searches. Based on these findings, it can be stated that when ETHEREUM's number of internet searches increases, particularly its price and its return are expected to increase. The results of the variance decomposition conducted for ETHERUM CLASSIC are presented on Table 8.

Table 8: Variance Decomposition Results for ETHERUM CLASSIC

\begin{tabular}{|c|c|c|c|c|c|}
\hline \multicolumn{7}{|c|}{ Variance Decomposition of PR: } \\
\hline Period & S.E. & ST & PR & RT & VOL \\
\hline 1 & 3,368166 & 37,02911 & 62,97089 & 0,000000 & 0,000000 \\
\hline 2 & 6,033650 & 48,82561 & 46,18106 & 4,583600 & 0,409731 \\
\hline 3 & 7,661625 & 48,58629 & 42,95752 & 7,786569 & 0,669620 \\
\hline 4 & 8,434244 & 46,18451 & 43,04952 & 9,618850 & 1,147127 \\
\hline 5 & 8,764177 & 44,38583 & 43,57809 & 10,52575 & 1,510334 \\
\hline \multicolumn{7}{|c|}{ Variance Decomposition of RT: } \\
\hline Period & S.E. & ST & PR & RT & VOL \\
\hline 1 & 36,55812 & 28,11650 & 14,83434 & 57,04916 & 0,000000 \\
\hline 2 & 44,72923 & 23,67622 & 9,921344 & 64,86380 & 1,538634 \\
\hline 3 & 46,58983 & 23,66990 & 10,85432 & 64,05550 & 1,420275 \\
\hline 4 & 48,66438 & 27,18408 & 11,90436 & 58,98205 & 1,929509 \\
\hline 5 & 50,21052 & 28,94557 & 13,68496 & 55,44658 & 1,922885 \\
\hline 6 & 50,76378 & 29,31830 & 13,93926 & 54,24571 & 2,496721 \\
\hline 7 & 51,03743 & 29,31665 & 14,43569 & 53,66804 & 2,579615 \\
\hline 8 & 51,30983 & 29,18011 & 14,31753 & 53,13236 & 3,369999 \\
\hline \multicolumn{7}{|c|}{ Variance Decomposition of VOL: } \\
\hline Period & S.E. & \multicolumn{5}{|c|}{ ST } & PR & RT & VOL \\
\hline 1 & 70,55692 & 0,377879 & 6,517389 & 0,021358 & 93,08337 \\
\hline 2 & 71,80969 & 2,530991 & 7,561163 & 0,021305 & 89,88654 \\
\hline 3 & 112,6504 & 1,429654 & 12,09991 & 3,382986 & 83,08745 \\
\hline 4 & 114,2860 & 2,273573 & 11,93754 & 5,062286 & 80,72660 \\
\hline 5 & 151,6081 & 1,710488 & 12,17945 & 6,983050 & 79,12701 \\
\hline 6 & 153,7938 & 2,529845 & 11,87512 & 8,692258 & 76,90278 \\
\hline 7 & 190,8924 & 2,115344 & 11,56139 & 9,370567 & 76,95270 \\
\hline
\end{tabular}

According to the results on Table 8, 46,1\% of the changes in ETHEREUM CLASSIC's prices, 29,3\% of the changes in ETHEREUM CLASSIC's returns and $2,5 \%$ of the changes in ETHEREUM CLASSIC's trading volume are determined by 
the frequency of internet searches. According to these findings, it can be explained that when ETHEREUM CLASSIC's number of internet searches increase, particularly its price and its return are expected to increase. The results of the variance decomposition performed for LITECOIN are shown on Table 9.

Table 9: Variance Decomposition Results for LITECOIN

\begin{tabular}{|c|c|c|c|c|c|}
\hline \multicolumn{7}{|c|}{ Variance Decomposition of PR: } \\
\hline Period & S.E. & ST & PR & RT & VOL \\
\hline 1 & 34,75752 & 94,58751 & 5,412494 & 0,000000 & 0,000000 \\
\hline 2 & 49,27223 & 96,18664 & 2,732700 & 0,191857 & 0,888798 \\
\hline 3 & 56,44069 & 95,95621 & 2,085554 & 0,153331 & 1,804909 \\
\hline 4 & 62,74079 & 95,64246 & 1,827091 & 0,173022 & 2,357422 \\
\hline 5 & 66,24516 & 95,27394 & 1,856682 & 0,299021 & 2,570354 \\
\hline \multicolumn{7}{|c|}{ Variance Decomposition of RT: } \\
\hline Period & S.E. & ST & PR & RT & VOL \\
\hline 1 & 58,79221 & 61,67199 & 7,246425 & 31,08158 & 0,000000 \\
\hline 2 & 62,49850 & 54,59760 & 6,942083 & 38,07974 & 0,380583 \\
\hline 3 & 63,31568 & 55,05848 & 7,368216 & 37,11840 & 0,454909 \\
\hline 4 & 64,26141 & 53,64579 & 7,633254 & 37,32674 & 1,394218 \\
\hline 5 & 65,34251 & 52,99640 & 7,396300 & 36,62296 & 2,984340 \\
\hline 6 & 66,11724 & 52,74684 & 7,284733 & 35,77301 & 4,195414 \\
\hline 7 & 66,89494 & 53,06603 & 7,219970 & 35,04924 & 4,664763 \\
\hline \multicolumn{7}{|c|}{ Variance Decomposition of VOL: } \\
\hline Period & S.E. & ST & PR & RT & VOL \\
\hline 1 & 48,91553 & 13,46326 & 0,055791 & 1,044677 & 85,43627 \\
\hline 2 & 80,89057 & 5,273470 & 2,449452 & 1,258758 & 91,01832 \\
\hline 3 & 99,91933 & 4,546916 & 4,177549 & 0,842323 & 90,43321 \\
\hline 4 & 108,4270 & 4,152071 & 5,845643 & 1,550771 & 88,45151 \\
\hline 5 & 111,1504 & 4,032423 & 6,761080 & 2,826250 & 86,38025 \\
\hline 6 & 111,8420 & 3,982759 & 7,012336 & 3,687004 & 85,31790 \\
\hline 7 & 112,3316 & 3,948692 & 6,972835 & 3,930662 & 85,14781 \\
\hline
\end{tabular}

According to the results on Table $9 ; 95,6 \%$ of the changes in LITECOIN's prices, $52,7 \%$ of the changes in LITECOIN's returns and $3,9 \%$ of the changes in LITECOIN's trading volume are determined by the frequency of internet searches. When the test results are examined, it can be stated that when LITECOIN's number of internet searches increases, particularly its price and its return are expected to increase. The results of the variance decomposition conducted for ZCASH are presented on Table 10. 
Table 10: Variance Decomposition Results for ZCASH

\begin{tabular}{|c|c|c|c|c|c|}
\hline \multicolumn{6}{|c|}{ Variance Decomposition of PR: } \\
\hline Period & S.E. & ST & PR & RT & VOL \\
\hline 1 & 60,50598 & 44,29354 & 55,70646 & 0,000000 & 0,000000 \\
\hline 2 & 96,42250 & 74,84290 & 25,11325 & 0,027318 & 0,016533 \\
\hline 3 & 120,2720 & 82,88179 & 16,66877 & 0,296882 & 0,152559 \\
\hline 4 & 133,4660 & 85,37863 & 13,58252 & 0,561126 & 0,477721 \\
\hline 5 & 139,6325 & 85,85907 & 12,41017 & 0,739380 & 0,991380 \\
\hline 6 & 142,1377 & 85,55665 & 11,99050 & 0,829880 & 1,622966 \\
\hline 7 & 143,1362 & 85,03593 & 11,83768 & 0,861112 & 2,265283 \\
\hline \multicolumn{6}{|c|}{ Variance Decomposition of RT: } \\
\hline Period & S.E. & ST & PR & RT & VOL \\
\hline 1 & 34,68527 & 33,82673 & 31,96643 & 34,20684 & 0,000000 \\
\hline 2 & 38,33827 & 40,64932 & 28,53505 & 30,18775 & 0,627881 \\
\hline 3 & 38,94488 & 39,40274 & 29,14944 & 29,76757 & 1,680258 \\
\hline 4 & 39,97398 & 40,90033 & 28,29863 & 28,28439 & 2,516645 \\
\hline 5 & 41,22046 & 43,69340 & 26,77371 & 26,61654 & 2,916355 \\
\hline 6 & 42,11962 & 45,74196 & 25,65650 & 25,55417 & 3,047368 \\
\hline 7 & 42,56041 & 46,69900 & 25,13069 & 25,09236 & 3,077953 \\
\hline 8 & 42,70380 & 46,97094 & 24,97983 & 24,96514 & 3,084092 \\
\hline 9 & 42,72905 & 46,98824 & 24,97235 & 24,95300 & 3,086404 \\
\hline \multicolumn{6}{|c|}{ Variance Decomposition of VOL: } \\
\hline Period & S.E. & ST & PR & RT & VOL \\
\hline 1 & 4580,000 & 5,212207 & 0,488178 & 1,010590 & 93,28902 \\
\hline 2 & 5927,053 & 3,127040 & 1,560713 & 1,038581 & 94,27367 \\
\hline 3 & 6797,346 & 4,281514 & 2,364905 & 0,949366 & 92,40422 \\
\hline 4 & 7518,899 & 8,426618 & 2,788744 & 0,805688 & 87,97895 \\
\hline 5 & 8157,686 & 13,51945 & 2,903172 & 0,684572 & 82,89280 \\
\hline 6 & 8703,318 & 17,96772 & 2,856181 & 0,608447 & 78,56765 \\
\hline 7 & 9143,860 & 21,21228 & 2,756831 & 0,567172 & 75,46371 \\
\hline 8 & 9484,004 & 23,32838 & 2,658061 & 0,545121 & 73,46844 \\
\hline 9 & 9740,089 & 24,60714 & 2,577639 & 0,531605 & 72,28361 \\
\hline 10 & 9931,574 & 25,34172 & 2,517532 & 0,521457 & 71,61929 \\
\hline 11 & 10075,72 & 25,75468 & 2,474445 & 0,512865 & 71,25801 \\
\hline
\end{tabular}

According to the results on Table 10, 85,5\% of the changes in ZCASH's prices, $46,9 \%$ of the changes in ZCASH's returns and 25,3\% of the changes in ZCASH's trading volume are determined by the frequency of internet searches. Based on these findings, it can be stated that when ZCASH's number of internet searches increases, its price, return and volume are expected to increase remarkably. 


\subsection{Causality Test}

In this study, since the series are stationary in their level values, the causality relations between the series were examined through the Granger (1969) causality test. This test is based on the study of Granger (1969) and has been up-dated and made reliable with additions and corrections made over time (Göçer, 2016).

This two-variable Granger causality test can be performed through the simultaneous equation system (Gujarati and Porter, 2012) as follows:

$$
\begin{aligned}
& X_{t}=\alpha_{0}+\sum_{i=1}^{m} \alpha_{i} X_{t-i}+\sum_{i=1}^{m} \beta_{i} Y_{t-i}+u_{t} \\
& Y_{t}=\theta_{0}+\sum_{i=1}^{m} \theta_{i} Y_{t-i}+\sum_{i=1}^{m} \gamma_{i} X_{t-i}+v_{t}
\end{aligned}
$$

Test hypotheses:

$H_{0}: \beta_{i}=0$ There is no causality relationship from $Y$ to $X$

$H_{1}: \beta_{i} \neq 0$ There is causality relationship from $Y$ to $X$

This test examines whether the $\beta_{i}^{\prime}$ in Equation (6) is equal to zero. When $\beta_{i}$ coefficients are different from zero at a certain level of significance, it can be concluded that there is a causality relationship from $Y$ to $X$. Similarly, if $\beta_{i}$ in Equation (7) are different from zero at a certain level of significance, it can be concluded that there is a causality relation from $\mathrm{X}$ to $\mathrm{Y}$. If both $\left(\beta_{i}, Y_{i}\right)$ are non-zero, it can be concluded that there is a mutual (bi-directional) causality relationship between these variables. If both parameters are equal to zero, it is decided that there is no causal relationship between the variables (Göçer, 2016).

Here $m$ in Equation (6) and Equation (7) refers to the optimum lag length. In this study, the optimum lag lengths in Table 4 were also used for the Granger causality test. The results are presented on Table 11. 
Table 11: Granger Causality Test Results

\begin{tabular}{|c|c|c|c|}
\hline & The Direction of Causality & F Statistics & Probability Value \\
\hline \multirow{6}{*}{ BITCOIN } & $P R \rightarrow S T$ & $5,46 * \star \star$ & 0,00 \\
\hline & $S T \rightarrow P R$ & $7,81^{* * \star}$ & 0,00 \\
\hline & $R T \nrightarrow S T$ & 0,15 & 0,99 \\
\hline & $S T \rightarrow R T$ & 0,33 & 0,96 \\
\hline & $V O L \nrightarrow S T$ & 0,43 & 0,92 \\
\hline & $S T \nrightarrow V O L$ & $519,94 * \star \star$ & 0,00 \\
\hline \multirow{6}{*}{ RIPPLE-XRP } & $P R \rightarrow S T$ & $14,96^{* * *}$ & 0,00 \\
\hline & $S R \rightarrow P R$ & $112,53 * * *$ & 0,00 \\
\hline & $R T \nrightarrow S T$ & 0,44 & 0,64 \\
\hline & $S T \rightarrow R T$ & 0,26 & 0,76 \\
\hline & $V O L \nrightarrow S T$ & 1,14 & 0,32 \\
\hline & $S T \nrightarrow V O L$ & 0,78 & 0,46 \\
\hline \multirow{6}{*}{ ETHEREUM } & $P R \rightarrow S T$ & 2,32 & 0,11 \\
\hline & $S T \rightarrow P R$ & $33,30 * * *$ & 0,00 \\
\hline & $R T \nrightarrow S T$ & 0,94 & 0,40 \\
\hline & $S T \nrightarrow R T$ & 2,45 & 0,10 \\
\hline & $V O L \nrightarrow S T$ & 0,15 & 0,85 \\
\hline & $S T+V O L$ & 0,07 & 0,92 \\
\hline \multirow{6}{*}{ ETHEREUM CLASSIC } & $P R \nrightarrow S T$ & $6,13^{* \star *}$ & 0,00 \\
\hline & $S T \nrightarrow P T$ & 1,49 & 0,24 \\
\hline & $R T \nrightarrow S T$ & $2,88^{*}$ & 0,07 \\
\hline & $S T \nrightarrow R T$ & 1,43 & 0,25 \\
\hline & $V O L \nrightarrow S T$ & 1,03 & 0,36 \\
\hline & $S T \nrightarrow V O L$ & 0,05 & 0,95 \\
\hline \multirow{6}{*}{ LITECOIN } & $P R+S T$ & 0,29 & 0,74 \\
\hline & $S T \nrightarrow P R$ & 0,71 & 0,49 \\
\hline & $R T \nrightarrow S T$ & 0,01 & 0,98 \\
\hline & $S T \nrightarrow R T$ & 0,98 & 0,38 \\
\hline & $V O L+S T$ & 0,01 & 0,98 \\
\hline & $S T \nrightarrow V O L$ & $3,12^{*}$ & 0,06 \\
\hline \multirow{6}{*}{ ZCASH } & $P R \nrightarrow S T$ & 0,29 & 0,59 \\
\hline & $S T \rightarrow P R$ & 80,90 *** & 0,00 \\
\hline & $R T \nrightarrow S T$ & 1,14 & 0,29 \\
\hline & $S T \nrightarrow R T$ & 0,21 & 0,64 \\
\hline & $V O L \nrightarrow S T$ & 0,00 & 0,99 \\
\hline & $S T \nrightarrow V O L$ & $3,36^{*}$ & 0,07 \\
\hline
\end{tabular}

Note: $\rightarrow$; It represents the $\mathrm{HO}$ hypothesis underlines that there is no causality relationship from the first variable to the second variable. * and ${ }^{* * *}$ mean that the hypothesis $\mathrm{HO}$ is rejected at the $10 \%$ and $1 \%$ significance level, and indicates that there is a causal relationship from the first variable to the second variable. 
According to the results of Table 11, in BITCOIN, there is a bidirectional causality relationship between the frequency of internet searches and the price and there is a unidirectional (one-way) causality relationship from frequency of internet searches to volume. In the RIPPLE-XRP, the bidirectional causality relationship between the frequency of internet searches and price has been observed while in ETHEREUM, unidirectional causality relationship from frequency of internet searches to the price was determined.

When the findings obtained were evaluated, this study found out that the frequency of internet searches for cryptocurrencies has a significant effect on price, return and trading volume. Based on this evidence, it can be concluded that increasing the ads and ensuring the reliability of these currencies will increase their prices, returns and trading volumes in the long term.

\section{Conclusion}

In this study, the relationship between the popularity (internet searches) of the cryptocurrencies and their prices, returns and trading volume is analyzed. The study aimed to find out that whether popularity can be explained by variable on prices, returns and trade volume of the cryptocurrencies. To carry out this analysis, the end-of-month closing prices, monthly trading volumes, monthly returns and monthly number of internet searches of cryptocurrencies were used. Since cryptocurrencies have different trading dates, the largest data period available for each currency is included in the analysis.

Since the period length of each cryptocurrencies is different, time series analysis was performed separately for each cryptocurrency included in the sample. In order to conduct time series analysis first structural break ADF unit test developed by Vogelsang and Perron (1998) was applied. All series in the analysis were observed as stationary and based on this finding regression analysis was made. According to results of the regression analysis, it was determined that there is a positive relationship between popularity and price, returns and trading volumes of the cryptocurrencies. It was observed that an increase in the frequency 
of internet searches of cryptocurrencies affected their prices, returns and trading volumes positively. The highest impact on prices and trading volume was observed in BITCOIN while the highest impact on returns was detected in LITECOIN. Since the popularity of the Bitcoin is obviously higher than other currencies, it was observed that to a 1 unit increase in internet searches, Bitcoin's prices may react by around 2,72 and Bitcoin's volume may react by around 4,1. This result may be helpful to explain huge price fluctuations which occur in Bitcoin. All results are statistically meaningful at $1 \%$ and $5 \%$ significant level.

To reveal dynamic interaction between the series VAR analysis was performed. Under the VAR analysis, the impulse-response functions and VAR decomposition analysis are performed respectively.

According to the findings of the impulse-response functions analysis, it can be claimed that there is a statistically meaningful interaction between the series. In this analysis, changes which occurred in the prices, returns and volumes of each of the cryptocurrencies against their popularity are determined. Except for LITECOIN, it is not possible to mention that all the dependent variables (prices, returns and volumes of the cryptocurrencies) are moving in the same direction with popularity. In LITECOIN, price, return and trade volume decrease in response to the decreasing shock of internet searches. Correlation of return is considered higher than price and trade volume. For other cryptocurrencies, different results are observed based on the different dependent variables. For instance, the return of BITCOIN indicates decreasing reaction against the decreasing shock of internet searches, but its price and volume fluctuates. In addition to this, this research concludes that for the RIPPLE-XRP, there is no statistically meaningful interaction between trading volume and internet searches.

In the variance decomposition analysis, we tried to determine how many of the changes which occurred in the prices, returns and transaction volumes of each cryptocurrency stemmed from itself and how many from the changes observed in other variables. Thus, an attempt was made to show the breakdown of the popularity effects on each cryptocurrency. Although different results may be seen 
for each crypto currency, it can be generalized that prices of all cryptocurrencies are determined by the internet searches of these currencies. Consistent with the results of the regression analysis, it can be stressed that there is a positive relation between prices and internet searches. When making comparison among the dependent variables, the highest correlation is observed between prices and internet searches. Except for Bitcoin results, the lowest correlation is observed between trade volume and internet searches. Despite these different results, it can said that all three dependent variables have a positive correlation with internet searches. It may be concluded that internet searches may be regarded as an important determinant factor for the performance of cryptocurrencies.

Finally, to find out causality relationship, the Granger causality test (1969) was performed. According to the causality test results, in BITCOIN and RIPPLE-XRP, there is a bidirectional causality relationship between the internet searches and the price. Based on this finding, it can be stated that both prices and internet searches mutually affect each other for BITCOIN and RIPPLE-XRP. There is a unidirectional (one-way) causality relationship from internet searches to volume in BITCOIN and from internet searches to price in ETHEREUM. Causality relationship in Litecoin and Ethereum Classic become weak compared to other currencies.

Based on the findings obtained from this study, it can be stated that the frequency of internet searches is becoming an important determinant for price, trading volume and monthly returns of crypto currencies.

Consequently, it can be concluded that informative meetings, advertisements, legal regulations, scientific publications and institutionalization to be held for these currencies will increase their returns and trading volumes in the long term and can give them greater roles in the future.

\section{Importance of Research and Contribution to Literature}

In this study, unlike the previous literature, the effect of the awareness of cryptocurrencies on price, return and transaction volumes is investigated. The 
main question of the study is whether the awareness of cryptocurrencies is an indicator that directs the price and transaction volume movements of cryptocurrencies.

\section{Limitations of the Research}

In the study, the awareness indicator was formed according to the frequency of searching for each cryptocurrency on the internet. The data range of the awareness indicator is not the same for each cryptocurrency.

As Bitcoin is the first digital currency, Bitcoin's awareness data is longer than other currencies. Only 6 cryptocurrencies were included in the analysis, with a sufficient time period to obtain a statistically significant result.

If the study is updated in the following years, longer observation data will be obtained for cryptocurrencies and the results obtained by including more cryptocurrencies in the sampling will be more generalized.

\section{Proposed Further Researches}

In this study, the interaction between the awareness indicator of cryptocurrencies and their price, return and transaction volumes is examined. It is strongly recommended that other studies be conducted to enable a forecasting analysis to be made for the relative future position of cryptocurrencies based on the awareness indicator.

Grant Support: The author received no financial support for this work.

\section{References}

Böhme, R., \& Christin, N. (2015). Bitcoin: Economics, Technology, and Governance, Journal of Perspectives, 29(2), 213-238,

Dikmen, N. (2012). Ekonometri Temel Kavramlar ve Uygulamalar. Dora Yayınevi, Bursa. 
Google. (2019). 25.05.2019. Retrieved from google.trends.com

Göçer, İ. (2016). Lisans ve Lisansüstü Için Ekonometri. Lider Yayınları, İzmir.

Granger, C. W. J. (1969). Investigating Causal Relations by Econometric Models and Cross Spectral Methods. Econometrica, 37, 424-438,

Gujarati, N. G., \& Porter, D. C. (2012). Temel Ekonometri, Çev. Ümit Şenesen ve Gülay Günlük Şenesen, (Orijinali: 5. Basım), Literatür Yayıncılık, İstanbul.

Habertürk. (2017). Bitcoin Artık Japonya'da Yasal. 29.05.2019. Retrieved from https://www. haberturk.com/ekonomi/teknoloji/haber/1453992-bitcoin-artik-japonyada-yasal

Siberbülten. (2017). Ukrayna Bitcoin'i Yasallaştırıyor, Madencilik Faaliyetleri Artıyor. 29.05.2019. Retrieved from https://siberbulten.com/bitcoin/ukrayna-bitcoini-yasallastiriyor-madencilikfaaliyetleri-artiyor/

Tarı, R. (2012). Ekonometri. Umuttepe Yayınları, Kocaeli.

Vogelsang, T. J., \& Perron, P. (1998). Additional Test for Unit Root Allowing for a Break in the Trend Function at an Unknown Time. International Economic Review, 39, 1073-1100. 
